\title{
Ohjeita, tietoa ja turvaa kielen keinoin. Ulkomailta palkatut sairaanhoitajat ammatillista suomen kielen taitoaan osoittamassa
}

\author{
MARJA SEILONEN, MINNA SUNI \\ Jyväskylän yliopisto
}

Tiivistelmä. Artikkelissa tarkastellaan neljän ulkomailla kouluttautuneen Suomessa työskentelevän sairaanhoitajan ammatillisen kielen käyttöä ja hallintaa. Aineistona ovat ammatillisen kielitaidon arviointia varten tutkimuskäyttöön laaditun arviointimoduulin suoritukset. Moduuliin sisältyi erilaisia integroituja aineistopohjaisia tehtäviä, jotka oli kehitetty Terveydenhuollon suomi: suomen kielen taidon kehittäminen ja arviointi terveydenhuollon alalla -hankkeessa (2014-2015). Ammatillisen kielitaidon arviointikokeilun tarkoituksena oli täydentää niitä kielitaitoprofiileja, jotka Yleisten kielitutkintojen keskitason suoritusten perusteella voidaan tunnistaa. Suoritusten laadullisella analyysilla pyritään saamaan selville, miten osallistujat hyödyntävät erilaisia syntaktisia, leksikaalisia ja pragmaattisia resursseja ilmaistakseen sellaisia terveysviestinnälle ominaisia kielenkäytön funktioita kuin ohjeiden antaminen ja tietojen kirjaaminen. Tarkastelun kohteena ovat myös heidän taitonsa toteuttaa siirtymiä ammatillisen ja arkisen rekisterin välillä. Sekä tämä kielenpiirteisiin keskittyvä analyysi että taustaksi tehty palautehaastattelujen sisällönanalyyttinen tarkastelu tuovat esiin, että osallistujat ovat varmempia ammatillisen kielen kuin ns. tavallisen kielen käyttäjinä, mikä selittyy sillä, että heidän kielitaitonsa on kehittynyt paljolti juuri työpaikalla 
ammatillisissa yhteyksissä. Havainto on tärkeä mm. maahanmuuttajien työelämäsuuntautuneen kielikoulutuksen kehittämisen kannalta.

Avainsanat: suomi toisena kielenä; maahanmuutto; ammatillinen kielitaito; kielitaidon arviointi; terveysviestintä

\section{Johdanto}

Työperusteista maahanmuuttoa on Suomessa viime vuosina edistetty erityisesti terveydenhuollon alalla, koska yleisen työllisyystilanteen heiketessäkin tällä alalla on koettu ja ennakoitu huomattavaa työvoimapulaa. Vuonna 2012 jo 8,4 \% lääkäreistä, 5,7 \% hammaslääkäreistä ja 3,3, \% sairaanhoitajista oli ulkomailla syntyneitä, mikä tarkoittaa, että näissä ammateissa toimii maahanmuuttajia suhteessa enemmän kuin heitä on maan kokonaisväestössä (Tilastoraportti 2012). Laillistuksen terveydenhuollon ammatin harjoittamiseen Suomessa on viime vuosikymmenen aikana saanut vuosittain noin 600 ulkomaan kansalaista (OKM 2014).

Työtehtävissä riittävän kielitaidon kysymykset ovat eri ammattiryhmien kansainvälistymisen myötä nousseet keskusteluun terveydenhuollon alalla, ja eri ministeriöiden ja asiantuntijatahojen edustajista muodostettiin vuonna 2013 työryhmä pohtimaan alan laillistamisprosesseihin sisältyviä kielitaitokysymyksiä ja koulutusväylien kehittämistä. Työryhmä päätyi muistiossaan esittämään, että kielitaitovaatimus nostettaisiin jatkossa Yleisten kielitutkintojen tasolta 3 tasolle 4 ( Eurooppalaisen viitekehyksen tasolta B1 tasolle B2) ja myös ammatillista kielitaitoa alettaisiin arvioida (OKM 2014). Näistä ei kuitenkaan ole tähän mennessä tehty päätöksiä. Myös kielitaitovaatimusten ulottaminen muihinkin kuin EU/ETA-alueen ulkopuolella terveydenhuollon tehtäviin kouluttautuneisiin oli raportissa esillä, ja tämän on direktiivimuutos nyt mahdollistanut vuoden 2016 alusta alkaen.

Työryhmän ehdotusten pohjaksi ei ollut käytettävissä kovin paljoa tutkimustietoa esimerkiksi nykyisin laillistamiseen edellytetyn 
kielitaidon eli Yleisten kielitutkintojen tason 3 riittävyydestä suhteessa terveydenhuollon työtehtäviin (ks. kuitenkin Kela \& Komppa 2011) eikä ammatillisen suomen kielen taidon arvioinnista tällä alalla. Osana opetus- ja kulttuuriministeriön sittemmin rahoittamaa Terveydenhuollon suomi: ammatillisen kielitaidon kehittäminen ja arviointi terveydenhuollon alalla -hanketta (Jyväskylän yliopisto, 2014-2015) on nyt toteutettu ammatillisen kielitaidon arviointikokeilu, jonka tuottamasta laajemmasta aineistosta on tämän artikkelin pohjaksi valittu neljän osallistujan suoritukset lähempään kvalitatiiviseen tarkasteluun.

Näillä neljällä osallistujalla on keskenään yhdenmukaiset kieli- ja koulutustaustat: he ovat espanjankielisiä sairaanhoitajia, jotka ovat siirtyneet rekrytointihankkeessa tarjotun yhteisen lähtömakkoulutuksen (ks. Raunio 2013) jälkeen Espanjasta töihin suomalaiseen sairaalaan. Kaikki olivat työskennelleet Suomessa 14-15 kuukautta, kun he osallistuivat Yleisten kielitutkintojen keskitason tutkintoon ja sen jälkeen ammatillisen kielitaidon arviointikokeiluun. Vaikka tässä raportoitava analyysi kohdentuu vain osallistujien ammatillisen kielitaidon moduulin suorituksiin, myös heidän Yleisten kielitutkintojen tuloksensa sekä arviointikokeilun jälkeen antamansa osallistujapalaute ovat mukana tausta-aineistona. Kolme neljästä saavutti tason 3 useimmissa tai kaikissa Yleisten kielitutkintojen osakokeissa ja neljäskin niistä yhdessä, mutta kukaan ei yltänyt missään osakokeessa vielä tasolle 4. Niinpä heidän tuotoksensa ammatillisen kielitaidon moduulissa havainnollistavat nimenomaan sitä, miten ammatillinen kielenkäyttö sujuu siinä vaiheessa, kun yleiskielitaito jää alle edellä mainitussa muistiossa (OKM 2014) ehdotetun vaatimustason 4.

Ammatillisen kielitaidon arviointikokeilun suoritusten analyysi painottuu sellaisiin kielellisiin funktioihin ja käytänteisiin, jotka on aiemmassa tutkimuksessa ja tarveanalyyseissa osoitettu suomenkielisen terveysalan vuorovaikutuksen kannalta keskeisiksi (esim. Kela \& Komppa 2011; Komppa ym. 2014; Seilonen \& Suni 2015) tai nostettu keskiöön alan kansainvälisessä tutkimuksessa (Moore ym. 2015; ABIM 2015). Tutkimuskysymyksiä on kaksi: 1) Millaisin kielellisin keinoin 
arviointikokeilun osallistujat pyrkivät ohjaamaan ja neuvomaan potilasta, jakamaan tietoa ja kehottamaan toimintaan sekä raportoimaan potilaan tilanteesta? 2) Millaisin kielellisin keinoin he rakentavat turvallisuudentunnetta, osoittavat empatiaa ja kuvaavat hoitotoimenpiteitä potilaalle tai tämän omaiselle? Analyysin tulosten valossa pohditaan lopuksi sitä, miten ammatillisen kielitaidon arviointi täydentää sitä kuvaa osallistujien kielitaidosta, joka yleisten kielitutkintojen tulosten pohjalta muodostuu, ja mitä koulutuksellisia päätelmiä tulosten varassa voidaan tehdä.

\section{Terveysalan kielelliset käytänteet ja toisen kielen käyttö tutkimuskohteina}

Kiinnostus kansainvälisen terveydenhuollon ammattihenkilöstön toisen kielen käyttöä ja kielitaitoa kohtaan on voimistunut sekä kansainvälisesti että Suomessa. Tutkimus, jonka Duff, Wong ja Early (2002) tekivät terveydenhuollon ammattilaisten kielitaidon tarpeesta ja käytännöistä, on ollut alalla merkittävä avaus. Erityisesti vuorovaikutuksen ja toiminnan näkökulmista kielitaidon tarpeita ovat tarkastelleet Roberts ja Sarangi (2005), Sarangi (2010) sekä Moore ym. (2015). He ovat myös tehneet analyysia autenttisista työtilanteista. Australiassa Candlin ja McNamara ovat edistäneet terveydenhuollon alan toisen kielen käyttäjien ammatillisen kielitaidon arviointitutkimusta (ks. esim. Candlin 2002; McNamara 2009) englannin kielen osalta, ja sinne onkin kehittynyt erityisen vahva ammatillisen kielitaidon arvioinnin osaamiskeskus.

Juuri Australiassa on kehitetty kansainvälisesti eniten käytetty terveysalalle suunnattu, ammatillinen englannin kielen testi Occupational English Test (OET). Siinä arvioinnin kohteena ovat vuorovaikutuksen yleisen tehokkuuden ohella sujuvuus, ymmärrettävyys, kielen sopivuus sekä kieliopilliset ja ilmaisulliset resurssit. Viimeaikainen tutkimus on tarjonnut näiden rinnalle etenkin konsultaatiotilanteiden arvioinnin osalta vielä kliinisen hoitotyön osaamista ja vuorovaikutuksen hallintaa, jotta arvioinnin alakohtainen relevanssi vahvistuisi (Pill 2016). Kaiken 
kaikkiaan terveydenhuollon kielen hallintaa siis arvioidaan melko yleisin kriteerein, mutta myös kliinisen ja kielellisen osaamisen suhdetta on jouduttu pohtimaan. Hoitotyötä on vaikeaa tehdä tehokkaasti, jos vuorovaikutus ei toimi, joten sujuvaa kommunikaatiota voi pitää myös kliinisten taitojen perusedellytyksenä. (Zetkulic 2011: 134, 141.) Ammatillinen kielitaito ei siten ole pelkästään asiantuntijuuden oheistaito vaan keskeinen osa ammattitaitoa (Härmälä 2008: 53), ja erityisesti suullisen viestinnän taitoa on alalla pidetty tärkeänä (esim. Elder ym. 2012).

Terveydenhuoltoalan työssä vuorovaikutustilanteissa on monenlaisia osapuolia, kuten oman ammattikunnan edustajia ja muita eri alojen kollegoja (Candlin \& Roger 2013: 153-154) sekä potilaita, asiakkaita ja heidän omaisiaan (Kela \& Komppa 2011). Tästä seuraa, että työympäristössä ovat käytössä monenlaiset kielelliset rekisterit - ei vain ammattikieli vaan myös yleiskielen normitettu variantti ja arkiset kielenkäytön muodot (Kela \& Komppa 2011: 183-188; Piikki 2010). Työssä on siis osattava varioida kielenkäyttöään erilaisissa tilanteissa ja hallittava niihin liittyviä sosiaalisia käytänteitä.

Terveydenhuollon vuorovaikutustaitojen arvioinnissa on fokusoitu esimerkiksi kysymisen, ohjeiden antamisen ja vastaamisen taitoon (potilashaastattelu), empatian ja myötätunnon ilmaisemisen sekä lohduttamisen taitoon (ammatillisuus) ja lääketieteellisen testin tai hoidon tarpeen perustelemisen taitoon (potilasneuvonta) (ABIM 2015). Näihin taitoihin sisältyy myös toimiva suullisen ilmaisun taito, mikä osoittaa, että kielitaito on tiiviissä yhteydessä muuhun ammattitaitoon. Suomessa vuorovaikutuksen rakentumista tarkastelee Jenny Paananen väitöstutkimuksessaan, joka on osa Turun yliopiston Monikulttuuriset kohtaamiset lääkärin vastaanotolla -hanketta (ks. Paananen 2015).

Kela ja Komppa (2011) ovat tutkineet englanninkielisen sairaanhoitajakoulutuksen suomea toisena kielenään puhuvien opiskelijoiden kokemuksia suomenkielisestä työharjoittelusta ja nostaneet keskusteluun etenkin kysymyksen yleisen ja ammatillisen kielitaidon suhteesta. Havaintojensa pohjalta he ovat myös päätyneet arvioon, että sairaanhoitajan tehtävät edellyttävät käytännössä B2-tasoista kielitaitoa. 
KOTI-hankkeessa taas on eritelty sairaanhoitajien työtehtäviä suomen kielen taidon tarpeen kannalta (Komppa ym. 2014); hankkeessa laadittiin ns. ammatilliset viitekehykset useille korkea-asteen koulutusaloille sairaanhoitajan ammatti mukaan lukien.

Virtasen $(2011 ; 2013 ; 2015)$ Jyväskylän yliopiston Suomi työkielenä -hankkeessa tekemä väitöstutkimus puolestaan tarkastelee sitä, miten englanninkielisen sairaanhoitajakoulutuksen opiskelijat, joilla suomi on toisena kielenä, kehittävät suomen kielen taitoaan, toimijuuttaan ja ammatti-identiteettiään erityisesti työharjoittelujensa myötä. Etnografisessa tutkimuksessaan Virtanen on havainnut, että työyhteisön tuki on keskeistä mm. kirjaamiskäytänteiden haltuunotossa ja ylipäänsä toimijuuden vahvistamisessa. Tulkinnat oman kielitaidon riittävyydestä eri työtilanteisiin ovat sosiaalisesti rakentuvia: sillä, miten ohjaajat ja työtoverit positioivat opiskelijan, on suuri merkitys hänen kielitaitoaan koskevien käsitystensä ja ammatillisen orientaationsa kannalta. Työyhteisön tuki on korostunut vahvasti myös haastatteluaineistoon perustuvissa maisterintutkielmissa, joiden fokuksessa olivat eräs maahanmuuttajalääkäri (Mähönen 2014) ja kyseistä lääkäriä hänen kielenoppimisessaan tukeneet työtoverit (Heimala-Kääriäinen 2015). Tervola ym. (2015) taas ovat tarkastelleet lääkäreiden laillistamiskuulusteluissa tuottamia kirjallisia koevastauksia erityisesti sanastopiirteiden kannalta ja hakeneet niistä selitystä sille, miksi Yleisten kielitutkintojen tason 3 suorittaneet osallistujat eivät välttämättä suoriudu kyseisistä kuulustelusta. Tervola tekee tähän aihepiiriin liittyvää väitöskirjaa Tampereen yliopistossa.

Terveydenhuollon suomi -hankkeen aiemmassa vaiheessa on jo havaittu, että terveydenhuollon alalle kouluttautuneilla on taipumusta tuoda esiin ammatillista kielitaitoaan myös Yleisten kielitutkintojen testissä, vaikka tehtävät eivät sitä edellytä eivätkä siihen ohjaa. Erityisen selvästi tämä näkyy heidän temaattisissa ja sanastollisissa valinnoissaan sekä tiettyjen työympäristössä toistuvien konstruktioiden ja syntaktisten mallien käytössään. (Seilonen 2014; Seilonen \& Suni 2015.) Tulokset antavatkin selviä viitteitä siitä, että työympäristö on keskeinen kielenoppimis- ja käyttöympäristö ja työelämän kieli saattaa monelle 
olla se kaikkein tutuin ja käytetyin puoli suomen kielestä. Ammatillisen kielitaidon arvioinnin onkin todettu tarjoavan työelämässä kielitaitoaan kehittäneille erityisen otollisen ja reilun mahdollisuuden osoittaa kielitaitoaan, koska ammatillinen puoli voi olla juuri vahvin osa heidän kielitaitoprofiilistaan (Hamp-Lyons 1991).

\section{Aineisto ja menetelmä}

Kaikkien osallistujien $(\mathrm{n}=35)$ kielitaitoa on Terveydenhuollon suomi -hankkeessa arvioitu kaksivaiheisesti: he suorittivat ensin Yleisten kielitutkintojen suomen kielen keskitason testin, johon sisältyvät puhumisen, kirjoittamisen, puheen ymmärtämisen ja tekstin ymmärtämisen osakokeet. Tämän jälkeen he suorittivat Terveydenhuollon suomi -hankkeessa tutkimuskäyttöön laaditun ammatillisen kielitaidon arviointimoduulin, jossa oli hoitoalan työtehtäviä myötäileviä integroituja tehtäviä, jotka edellyttivät kirjoittamista videoidun puhenäytteen pohjalta ja puhumista kirjallisen tekstin pohjalta. Kaikki tehtävät tehtiin itsenäisesti tietokoneella. Tehtävissä oli rinnakkain läsnä monta ammatilliseen kielenkäyttöön liittyvää ulottuvuutta: tekstin funktio (tiedon tai ohjeiden antaminen, kuvaus ja dokumentointi), lähdemateriaalin rekisteri (ammatillinen ja yleinen), viestin kohdentaminen (kohteena saman alan ammattilainen tai potilas/asiakas tai potilaan omainen) ja rekisterin muunnos (ammatillisesta yleiseen ja yleisestä ammatilliseen). Tehtävätyyppejä kuvataan lähemmin analyysin yhteydessä.

Tässä artikkelissa keskitytään neljän sairaanhoitajan tuotoksiin ammatillisen kielitaidon moduulissa. Näiden neljän testisuoritukset on valittu siksi, että heillä on samankaltainen kielitausta, muuttohistoria ja toimenkuva Suomessa. Osallistujien pseudonyymeissä NE1-4 kirjain N viittaa sukupuoleen (nainen) ja E äidinkieleen (espanja). Osallistujien taustatiedot ja yleisten kielitutkintojen tulokset on koottu taulukkoon 1. 
Taulukко 1. Osallistujien taustatiedot ja Yleisten kielitutkintojen (YKI) tulokset

\begin{tabular}{|c|c|c|c|c|}
\hline Taustatiedot & NE1 & NE2 & NE3 & NE4 \\
\hline ikä & $27 \mathrm{v}$ & $38 \mathrm{v}$. & $28 \mathrm{v}$. & $48 \mathrm{v}$ \\
\hline $\begin{array}{l}\text { aika ammat- } \\
\text { tiin valmistu- } \\
\text { misesta }\end{array}$ & $1 \mathrm{v} .4 \mathrm{kk}$ & $15 \mathrm{v}$. & $6 \mathrm{v}$. & $10 \mathrm{v}$ \\
\hline $\begin{array}{l}\text { Suomessa- } \\
\text { asumisaika }\end{array}$ & $1 \mathrm{v} .3 \mathrm{kk}$ & 1 v. $3 \mathrm{kk}$ & $1 \mathrm{v} .2 \mathrm{kk}$ & 1 v. $3 \mathrm{kk}$ \\
\hline $\begin{array}{l}\text { opiskellut } \\
\text { suomea }\end{array}$ & $\begin{array}{l}\text { Espanjassa } \\
4 \mathrm{kk}, 25 \mathrm{t} / \mathrm{vko} ; \\
\text { Suomessa } 1 \mathrm{v}, \\
2-4 \mathrm{t} / \mathrm{vko}\end{array}$ & $\begin{array}{l}\text { Espanjassa } \\
4 \mathrm{kk}, 25 \mathrm{t} / \mathrm{vko} ; \\
\text { Suomessa } 1 \mathrm{v}, \\
2-4 \mathrm{t} / \mathrm{vko}\end{array}$ & $\begin{array}{l}\text { Espanjassa } \\
4 \text { kk, } 25 \text { t/vko; } \\
\text { Suomessa 1 v, } \\
\text { 2-4t/vko }\end{array}$ & $\begin{array}{l}\text { Espanjassa } \\
4 \mathrm{kk}, 25 \mathrm{t} / \mathrm{vko} ; \\
\text { Suomessa } 1 \mathrm{v}, \\
2-4 \mathrm{t} / \mathrm{vko}\end{array}$ \\
\hline työ Suomessa & $\begin{array}{l}\text { sairaanhoita- } \\
\text { jana } 1 \text { v. } 3 \mathrm{kk}\end{array}$ & $\begin{array}{l}\text { sairaanhoita- } \\
\text { jana } 1 \text { v. } 3 \mathrm{kk}\end{array}$ & $\begin{array}{l}\text { sairaanhoita- } \\
\text { jana } 1 \text { v. } 2 \mathrm{kk}\end{array}$ & $\begin{array}{l}\text { lähihoitajana } \\
1 \mathrm{v} .3 \mathrm{kk}\end{array}$ \\
\hline työ muualla & $9 \mathrm{kk}$ & $\begin{array}{l}10 \mathrm{v} .+2 \mathrm{v} \\
\text { Italiassa }\end{array}$ & & $10 \mathrm{v}$ \\
\hline $\begin{array}{l}\text { suomen } \\
\text { kielen käyttö }\end{array}$ & $\begin{array}{l}\text { työssä, asioin- } \\
\text { nissa }\end{array}$ & $\begin{array}{l}\text { työssä, asioin- } \\
\text { nissa }\end{array}$ & $\begin{array}{l}\text { työssä, asioin- } \\
\text { nissa }\end{array}$ & $\begin{array}{l}\text { työssä, asioin- } \\
\text { nissa }\end{array}$ \\
\hline $\begin{array}{l}\text { YKI-tulokset } \\
\text { (puhuminen, } \\
\text { puheenym- } \\
\text { märtäminen, } \\
\text { kirjoitta- } \\
\text { minen, } \\
\text { tekstinym- } \\
\text { märtäminen) }\end{array}$ & $3,3,3,3$ & $3,3,<3,3$ & $3,3,3,3$ & $<3,3,<3,<3$ \\
\hline
\end{tabular}

Kaikkien neljän osallistujan äidinkieli ja kotona käyttämä kieli on espanja, ja kaikki ovat tulleet Suomeen saman rekrytointihankkeen kautta samana vuonna ja työskennelleet suomalaisessa sairaalassa osastolla jokseenkin yhtä pitkään. Yhtä lukuun ottamatta kaikki toimivat Suomessa sairaanhoitajina, ja neljäskin on toiminut saman ajan lähihoitajana. Ikä ja lähtömaassa kertynyt työkokemus sen sijaan vaihtelevat melko paljon: nuorin osallistujista ehti lähtömaassaan työskennellä sairaanhoitajana alle vuoden ennen Suomeen-muuttoaan, kun kahdella työkokemusta oli noin kymmenen vuotta; yhden osalta tieto on epätarkka. 
Analyysi kohdistuu osallistujien ammatilliseen kielitaitoon erilaisten kielenkäytön funktioiden ja käytänteiden kautta, ja menetelmällisesti se rakentuu siten, että ammatillisten tekstilajien ja niiden sanasto- ja rakennepiirteiden tarkastelu on alisteista funktionaaliselle ja pragmaattiselle näkökulmalle. Keskiössä on se, kuinka osallistujat ilmaisevat tiettyjä kielellisiä funktioita ja muuntavat rekisteriä tilanteen mukaan, ja tätä lähestytään suoritusten sanaston ja rakenteiden tasoa analysoiden.

Tarkastelun kohteena olevat kielelliset funktiot ovat tiedon antaminen ja ohjaus, toimintaan kehottaminen ja viestin kohdentaminen sekä luottamuksen rakentaminen ja rauhoittelu. Lähtökohtana on toiminnallinen kielitaitokäsitys, jota myös Eurooppalainen viitekehys (2003) edustaa, ja kielen oppiminen nähdään käyttöön perustuvana prosessina. Kielellisten funktioiden ilmaisemista tarkastellaan myös sujuvuuden, tarkkuuden ja kompleksisuuden näkökulmasta (esim. Martin ym. 2010). Rakennepiirteiden erittelyssä tukeudutaan pääosin Ison suomen kieliopin kuvausmalleihin (VISK: §1254, §1263, §1286-1296).

Terveydenhuoltoalan tehtävissä keskeistä on hallita myös siirtyminen ammatillisen ja yleisen rekisterin välillä (Kela \& Komppa 2011), ja näitä kielellisiä käytänteitä tarkastellaan siksi vielä erikseen. Rekisterinvaihdoksia tarkastellaan siltä kannalta, miten eri osallistujat suoriutuvat saman ammattikielisen pohjatekstin muokkaamisesta arkikielisempään muotoon. Muutoin esimerkit on pyritty valitsemaan eri osallistujilta siten, että ne havainnollistavat samanaikaisesti sekä arviointikokeilussa käytettyjen tehtävätyyppien variaatiota että niitä työssä tarvittavien kielenkäytön funktioiden ilmaisemisen keinoja, jotka osallistujilla ovat kehittymässä. 


\section{Kielellisten funktioiden ilmaiseminen ja tilanteinen rekisteri}

\subsection{Tiedon antaminen ja ohjaus}

Ammatillisen kielitaidon arviontikokeilussa oli yhtenä tehtävänä laatia pienten lasten vanhemmille lyhyt ohjaava tiedote maitoallergian diagnosoinnin nykykäytänteistä; tiedote on ajateltu laitettavaksi saataville esimerkiksi neuvolan infokansioon. Lähdemateriaalina tässä ymmärtämistä ja kirjoittamista yhdistävässä tehtävässä on terveydenhuollon ammattilaisille suunnattu video (2:17 min), jossa lääketieteen asiantuntija kuvaa diagnosoinnin periaatteet ja kulun. Videossa asiantuntijan puhetta on ajoittain tukemassa tekstiä ja kuvioita yhdistävä esitysgrafiikka. Lähdemateriaali sisältää paljon asiantuntijatietoa ja ammattiterminologiaa tiiviissä muodossa, joten kirjoittajan oli yleistajuistamista tehdessään karsittava tietoa ja ratkaistava, mikä on kuulijan kannalta riittävä tiedon määrä ja ymmärrettävä esittämistapa. Tehtävä on aikapaineinen, sillä valinnat oli tehtävä ripeästi kahden katselukerran varassa.

Osallistuja NE3:n laatima ohjaava tiedote sisältää suppean oirekuvauksen, muutaman toimintaohjeen ja maininnan siitä, mille terveydenhuollon organisaation tasolle hoito kuuluu. Tiedote on niukka ja pelkistetty muistiinpanonomainen teksti. Se on tekstinä tiivis ja ymmärrettävä, mutta ei täytä tehtävänantoa siltä osin, että se muodostaisi nimenomaan vanhemmille suunnatun ohjeen.

(1) Maito allergia aiheuttaa paljon oireita kuten iho oireet ja suoli oireet.

Laitetaan sitten ruokavalion ilman maitoa eli maito eliminaatio.

Annetaan soija jos lapsi on yli puoli vuotta.

Tarpeeksi on perusterveydenhuolto ja tarvittaessa sunnitellaan jatkohoito ja lapsi pitäisi mennä erikoislääkäriin. (NE3)

NE3 on onnistunut valitsemaan laajasta materiaalista kaikkein keskeisimmät seikat ja yleistajuistamaan ne; keskeiset oireet ja hoidon kulku on kuvattu ja maitoeliminaatio on avattu lyhyesti ja selkeästi. Tekstistä on kuitenkin jätetty pois melko paljon yksityiskohtaisempaa, vanhemmille 
käytännön arjessa tarpeellista tietoa. NE3 ei mainitse esimerkiksi sellaisia videolla esitettyjä keskeisiä tietoja kuin minkä ikäisiä lapsia ohje koskee, millä alle puolivuotiaan lapsen maito korvataan tai koskeeko maito-eliminaatio myös imettävää äitiä vai ei. Informaation määrä on lähdemateriaalissa niin suuri ja esittämistapa niin tiivis, ettei kaikkien pääkohtien tunnistaminen ja valinta vielä onnistu aikapaineisessa tilanteessa tällä tarkkuudella.

NE3 ilmaisee toimintaohjeissa direktiivisyyttä pääosin passiivilla (laitetaan, annetaan, suunnitellaan), joka onkin tyypillinen erilaisissa ohjeissa ja säännöissä (VISK: $\$ 1655$ ). Tällöin toimintaan kehottaminen on epäsuoraa kohteen jäädessä jonkin verran tulkinnanvaraiseksi, mikä voi johtaa myös epäselvyyteen siitä, kenen pitäisi toimia (Hyvärinen 2005; Tiililä 2012). Toisaalta ohjaileville teksteille on myös ominaista, että kun ohjeistettu työ kuuluu jonkun tietyn toimijan vastuulle, tekijää ei tarvitse erikseen spesifioida (Honkanen 2012: 162). Koska allergian hoitoon osallistuvat hoitohenkilökunnan lisäksi myös lasten vanhemmat, passiivilla viitataan tässä tekstissä onnistuneesti kumpaankin osapuoleen. Lauseenalkuisena passiivi (laitetaan, annetaan) on kirjoitetuissa teksteissä harvinainen (VISK: \$1318) mutta suullisissa tilanteissa luonteva, tavallinen direktiivisyyden ilmaisin (VISK: \$1654). NE3 tukeutuu kirjallista ohjetta laatiessaan siis suullisista työelämän tilanteista tuttuun ohjaamisessa tarvittavaan ilmaustapaan; hän tulee näinkin ymmärretyksi, mutta muodolliseen rekisteriin liittyvä sävyjen ja sanajärjestysten hallinta on vasta kehittymässä.

Ammatillisen kielitaidon arviointikokeilun tehtävissä edellytettiin myös rekisterin muuntamista arkikielisestä ammatilliseen ja samalla suullisesta kirjalliseen muotoon (ks. lähemmin lukua 4.4). Yhdessä tehtävistä yleispuhekielisen videoidun lähdemateriaalin (1:28 min) aines oli muunnettava ammatillisen kielen mukaiseksi kirjaamalla potilaan kuvaama sairauskertomus kollegoja ja tulevia hoitotoimenpiteitä varten. Tämäntyyppinen tiedon dokumentointi on kaikessa hoitotyössä hyvin keskeistä (Tiililä 2010), ja sen haltuunoton haastavuus on tullut esiin alan suomalaisessa tutkimuksessa (Kela \& Komppa 2011; Virtanen 
2013). Esimerkki (2) on osallistuja NE1:n tekemä kirjaus. Se sisältää tiiviissä muodossa hoitotyön kannalta oleellisia seikkoja, kuten oireiden kuvauksen ja niiden keston, tähänastiset hoitotoimet ja niiden vaikuttavuuden sekä tämänhetkisen voinnin.

(2) Nuori nainen jolla on huono olo, itse kertoa tuntua samanlainen kun flunssa; oireet viime syksyllä sitten. Ylensä pikkusen korkea lämpö ja väsymys, vaikeasti tekee päivittäisissä toimissa.

Allergiatesti tehnyt, ei löytänyt positiivisen tuloksia.

Antihistamiini hoito ja nenäsuihke eivät auttaneet.

PEF seuranta tehty, ei diagnosoi Astma.

Selvitetään:

Onko potilaalla tupakointi käyttö?

Onko hänen paino laskenut tästä vuodesta?

Onko hänellä tervelista ruokavalio? (NE1)

Osallistujan NE1 tekemä kirjaus seuraa ilmaisultaan täysin tunnistettavasti kirjaamisen ja samalla joidenkin muidenkin terveydenhuollon alan genrejen, kuten sanellun hoitokertomuksen, kielellisiä käytänteitä. Teksti on tarkoituksenmukaisen tiivis, lyhyt ja selkeä, ja genrelle ominainen olla-verbin ellipsi toteutuu verbin nominaalisissa liittomuodoissa ilmauksissa allergiatesti tehnyt, PEF-seuranta tehty ja ei diagnosoi astma että eksistentiaalisessa rakenteessa ylensä pikkusen korkea lämpö ja väsymys. Vaikka aktiivin ja passiivin vaihtelu ei toteudu aivan kohdekielen mukaisesti, ilmaukset ovat kontekstissaan täysin ymmärrettäviä. Alakohtaisen ammatillisen kielen malleja voi nähdä myös tekijättömäksi jätetyssä ilmauksessa vaikeasti tekee päivittäisissä toimissa; ongelmana on vain sananvalinta, sillä verbin täydennys näyttää selviytyä-verbin mukaan valitulta (selviytyä päivittäisissä toimissa).

Kirjaaminen on hoitotyössä toistuva ja keskeinen tekstityön osaalue (Tiililä 2010: 164), joten sen haltuunotto on työn arjessa välttämätöntä jo alkuvaiheessa, vaikka ellipsi ja monet suomen kielen infiniittiset rakenteet, joita kirjaamisessa suositaan, ovat rakenteina kompleksisia ja siten jo melko edistyneelle taitotasolle sijoittuvia (Kela \& Komppa 2011). Kirjaamiselle ominaisten kielenpiirteiden hallinta on niin keskeistä, että 
sen on havaittu alan edustajilla heijastuvan välillä myös ammatillisen kontekstin ulkopuolisiin teksteihin, kuten henkilökohtaisiin viesteihin, joissa se ei olekaan yhtä luontevaa (Seilonen 2014: 229-230).

Esimerkki (3) on osallistuja NE2:n tekemä kirjaus, jossa hän käyttää arkikielellä puhuttua lähdemateriaalia enemmänkin suoraan siteeraten.

(3) Nuori tyttö ollut flunssa pitka aika, hänen oireita ollut: pääsärku, korkea kuumetta, kurkku kipeä, yski... aloitettu sysylla ja viellä hänellä ei tuntu hyvin. Nyt hänellä ei ole korkea kuumeta mutta hänellä tuntu paljon väsyttä ja lämpo joskus mennee alas ja joskus ulos. Hänellä on vähän pellota, hänellä tekin tammikussa allergiantestiin, astma, ruoka ja, elaime ja humeita. Mutta kaikki ollut hyvin, ei loudan eri kosta [ei löydy erikoista]. Lääkkäri määrräus: nenäsuihku ja antihiestaminiko mutta ei auta. (NE2)

NE2 toistaa puhujan mainitsemia oireita ja hänelle tehtyjen allergiatestien aiheita sellaisenaan, jolloin tekstistä muodostuu sinänsä tiivis, mutta liiankin luettelomainen listaus. Kirjoittajan oma panos tekstin tekijänä jää melko vähäiseksi, sillä hän ei yhdistele eikä tiivistä tietoa eikä muunna sitä kovinkaan kattavasti ammatilliseen rekisteriin. Myöskään edellä mainitut kirjaamisen tekstilajityyppiset vaativammat tunnusmerkit eivät vielä täyty. Kirjaukseksi tekstin kuitenkin tunnistaa jo siitä, että potilasta luonnehditaan alussa lyhyesti, hänen tilanteensa kehitys ja tehdyt tutkimukset kuvataan elliptisiä passiivirakenteita tapaillen ja myös nykytilanne kuvataan ja hoitosuunnitelma esitellään, joskin melko horjuvin kielellisin keinoin. Kirjoittajan kielitaito ei ilmeisesti riitä siihen, että hän pystyisi etääntymään lähdemateriaalin tyylistä ja kielellisistä muotoiluista ja tässä mielessä toimimaan itsenäisenä ammatillisen kielen käyttäjänä.

Teksti on vielä horjahtelevaa myös muotojen ja rakenteiden tasolla, ja vaikeuksia on lisäksi äänne-kirjain-vastaavuuden hahmottamisessa. Huomiota kiinnittää horjunta äänteiden keston merkinnässä (viellä, tammikussa, lääkkäri) ja $o$-, $u$ - ja $y$-vokaalien välisessä eronteossa (humeita, pääsärku, määrraus). Viimeksi mainittu ilmiö voi johtaa väärinymmärryksiin, kuten esimerkiksi kirjoittajan mainitessa potilaan 
osallistuneen allergiatestiin, jossa testattiin herkkyyttä homeille: hänellä tekin tammikussa allergiantestiin, astma, ruoka ja, elaime ja humeita. Konteksti tosin auttaa lukijaa ymmärtämään, että kyse ei ole huumeista. Huolimatta moninaisista tarkkuuden puutteista myös esimerkki (3) osoittaa, että kirjaaminen on toimintana ja tekstilajina jo tuttu ja siitä on saatu käytännön tuntumaakin, jonka turvin tätä ammatillisen kielenkäytön aluetta on päästy ottamaan haltuun.

\subsection{Epäsuoruus henkilöviittauksissa ja toimintaan kehottamisessa}

Hoitosuhde, jossa asiantuntija ja potilas kohtaavat, on yleensä luonteeltaan institutionaalinen ja hierarkkinen (Haakana \& Raevaara 1999; Paananen 2015). Hoidon onnistumiseksi potilaan tulee noudattaa asiantuntijan antamia ohjeita ja suostua hänen tekemiinsä toimenpiteisiin. Tilanteissa valta on tyypillisesti asiantuntijalla ja potilas on toiminnanalainen kohde. Tämän valtasuhteen (ks. De La Croix \& Skelton 2009) häivyttämiseksi kielen tasolla käytetään esimerkiksi epäsuoria ilmauksia. Hyvän hoitosuhteen luomiseksi suomea toisena kielenään käyttävän hoitajan onkin tärkeää osata antaa ohjeita ja käsitellä sensitiivisiä asioita epäsuorasti, potilaan kasvoja uhkaamatta.

Kielellinen epäsuoruus liittyy kohteliaaksi tulkittuun kielenkäyttöön, jossa kielellisin keinoin esimerkiksi huomioidaan vastaanottajaa ja vähennetään puhujan vaikutusvaltaa. Yhtäältä epäsuoruudella häivytetään puhujan kuviteltua tai todellista valtaa suhteessa kuulijaan ja toisaalta minimoidaan hänen rooliaan aktiivisena toimijana. Epäsuorin viittauksin hälvennetään toimintapyynnön käskynomaisuutta ja osoittelevuutta eli liian suoraa pyynnön kohdennusta. Kun toimintaan kehottamista ei kohdenneta suoraan puhuteltavalle, hänelle annetaan ainakin kuvitteellinen liikkumavara siinä, tulkitseeko hän kehotuksen koskevan juuri itseään ja noudattaako hän tulkintansa pohjalta kehotusta vai ei (esim. Brown \& Levinson 1987: 61). 
Esimerkissä (3) NE3 antaa potilaalle suullisesti toimintaohjeita tiettyyn lääketieteelliseen tutkimukseen valmistautumiseen; hänen tehtävänään on mukauttaa pitkähkö, kielimuodoltaan kompleksinen kirjallinen ohje iäkkäälle potilaalle selkeään ja ymmärrettävään muotoon. NE3 onnistuu informaation valinnassa, selkeyttämisessä ja kohdentamisessa hyvin. Hän ilmaisee taitavasti nollapersoonan avulla, että ohjeet ovat yleisiä ja koskevat siten ketä tahansa vastaavassa hoitotilanteessa olevaa asiakasta; myönteiset ja kielteiset nollapersoonamuodot on esimerkissä lihavoitu.

(4) --- puhdas tukka ja kuiva tukka, ei saa laittaa mitään. ei saa käyttāä esimerkiksi shampoo. ei, no tutkimuspäivä saa syödä ja juoda. ja annetaan varmasti esilääke. ja. pitäs, antaa meille. lääke sinun oma lääketiedot. sitten, no, tutkimuksessa, laitetaan elek-, tro- elektrodit, päässä, ja pitää olla rentona ja, silmät, kiini. (NE3)

Persoonaviittausten pitäs antaa meille ja sinun oma lääketiedot avulla NE3 vielä tarkentaa kohdennusta ja eksplikoi, että ohje koskee juuri käsillä olevan tilanteen toista osapuolta, kuulijaa. NE3 hallitsee siis jo hyvin epäsuoruuden ja suoruuden varioinnin ja pystyy lähestymään iäkästä potilasta tilanteen vaatimalla tavalla.

Epäsuorasti voidaan viitata myös puhujaan itseensä tai muuhun tiettyyn henkilöön, jolloin heidän merkitystään toimijana ei painoteta, vaan huomio suunnataan toimintaan. (VISK: $\$ 1254$.) Tästä on kyse esimerkissä (5): potilaan hoitotoimenpiteistä kertoessaan puhuja NE3 käyttää passiivimuotoja laitettiin, annetaan, laitetaan, joiden avulla hän siirtää agentin, hoitohenkilökunnan edustajat, toiminnan kuvauksessa taustalle. Tehtävässä NE3 selvittää lukemansa potilasasiakirjatekstin pohjalta omaisille puhelimitse, miten potilasta on viime aikoina hoidettu.

(5) laitetiin myös, verta tippuman koska hemoglobiini oli mattala. verenpaine on, on tällä hetkelä, normaali, ja. nut annetan hänele, piikki vatsassa koska, ei saa antaa Marevan hänele. (NE3)

Passiivin luonteeseen kuuluu myös implisiittinen viittaus monikolliseen agenttiin (VISK: $\$ 1256$ ), joka tässä yhteydessä palvelee vaikutelmaa siitä, 
että potilaasta on huolehtimassa useampijäseninen hoitoalan ammattilaisten joukko. Toisaalta passiivilla voi myös yleistää (VISK: $\$ 1331$ ), jolloin tehdyt toiminnot näyttäytyvät tavallisina rutiinitoimenpiteinä, jotka vain tulevat tehdyksi ilman, että tekijää on tarpeen tuoda esiin. Yleistävyyden tulkintaa tukee tässä se, että myös nollapersoonainen ei saa antaa viittaa määrittelemättömään tekijään, kun taas passiivin ei saada antaa käyttö tässä yhteydessä implikoisi puhujaviitteisyyttä (ks. myös Seilonen 2013).

Persoonaton ilmaustapa ja epäsuoruus eivät kuitenkaan ole parhaita kielellisiä valintoja kaikissa terveydenhuollon vuorovaikutustilanteissa. Henkilökohtaisempi lähestymistapa on paikallaan esimerkiksi silloin, kun käsitellään kuulijalle vaikeita asioita ja halutaan samalla luoda luottamuksellista ilmapiiriä. Seuraavan alaluvun esimerkit liittyvät näihin tilanteisiin.

\subsection{Luottamuksen rakentaminen ja rauhoittelu}

Terveydenhuollon ammateissa ovat tavallisia työtilanteet, joissa keskeistä on potilaan tai hänen omaistensa luottamuksen herättäminen (Candlin \& Roger 2013: 48). Hoitotoimenpiteen kohteena oleva pyritään saamaan vakuuttuneeksi esimerkiksi siitä, että toimenpide on turvallinen ja että potilas on osaavissa käsissä (esim. Northouse \& Northouse 1998: 42). Pelokasta tai huolestunutta potilasta tai hänen läheisiään on myös tärkeää osata tarvittaessa rauhoitella.

Ammatillisen kielitaidon arviointikokeilussa oli yhtenä tehtävänä antaa kirjallisen hoitokertomuksen pohjalta omaiselle suullisesti tietoa iäkkään ja melko huonokuntoisen potilaan tilanteesta (ks. esim. 5 edellä). Tehtävässä potilasta koskevat tiedot eivät ole kovin rohkaisevia, joten suullisen raportin antajan on lähestyttävä potilaan omaista luottamusta herättävällä ja rauhoittavalla otteella. Hänen on myös muotoiltava ammatillista rekisteriä edustava teksti maallikolle ymmärrettäväksi ja valittava siitä olennainen, ei-asiantuntijalle relevantti aines.

Esimerkissä (6) hoitaja (NE1) pyrkii rauhoittelemaan huolestunutta omaista toteamalla potilaan terveydentilasta myönteisiä asioita erilaisin 
eksistentiaalilausein ja modaali-ilmauksin: verenpaine on, kunnossa, ei oo kuumetta; hänellä on nyt hyvä vointia, hän voi kävellä nyt; ei oo mitään lonkkamurtumaa. Lisäksi hän mainitsee, että iäkkäillä paranemisprosessi ylipäätään on hidas, millä hän selittää syytä siihen, että puheena oleva henkilö on vuodepotilaana, vaikka lonkka ei olekaan murtunut. Tässä hän käyttää jälleen yleistäväksi tulkittavaa ilmausta ei se parantaa kun joku haava. Vaikka rakenteet ajoittain horjuvat, ymmärrettävyys säilyy ja viesti välittyy. Hoitajan kielenkäyttö on puheenvuorossa myös paikoin idiomaattista ja kokonaisuudessaan sujuvaa.

(6) joo kyllä, sinun, täällä, täällä osastolla on hoidossa, sinun äiti, joo, hetki pieni mä tarkistan vielä koneella hänen tiedot, joo. nii hän tullu tänään päivällä, ja, hän tullut Savon Sav- Savo Savosta sairaalasta, ja me ni meillä on, me ole-, me olemme vuodeosasto, ja hän tullut täällä varten jatkohoito, nyt hoitolinja se on, konsevativ-,nyt se on konservatiivinen hoitolinja, verenpaine on, kunnossa, ei oo kuumetta, -- sitten, joo me hoidetaan hän on nyt, hänellä on nyt hyvä vointia paitsi on vuoteessa, (hän) voi kävellä nyt, sä tiedät että hän kaatuu hän kaatunu kotona, joo, kohta kolme viikkoa sitten, ja, vaikka ei oo mitään lonkkamurtumaa, kun se on, vanhuus ja ei se, ei se parantaa kun joku haava [kun on vanha, kaatumisen aiheuttama vamma ei parane yhtä helposti kuin haava (NE1)

Sujuvuuden vaikutelmaa luovat esimerkiksi dialogipartikkeleiden käyttö vuoron avauksessa ja lopetuksessa (joo kyllä, sinun, täällä, täällä osastolla on hoidossa, sinun äiti, joo, hetki pieni mä tarkistan vielä koneella hänen tiedot, joo. nii hän tullu tänään päivällä) sekä puheen idiomaattiset prosodiset piirteet, kuten luonteva sävelkulun vaihtelu ja äänensävy.

Esimerkissä on erikseen lihavoitu ne kohdat, joissa turvallisuuden tunnetta luodaan ja lujitetaan persoonaviittauksin. Käyttämällä monikon ensimmäisen persoonan persoonaviittauksia me olemme vuodeosasto; me hoidetaan hoitaja synnyttää nimenomaan luottamusta potilaan omaisessa. Kun agentit nimetään, samalla ilmaistaan myös heidän asemansa toiminnasta vastuullisina tahoina: hoidosta vastaamme me (ks. myös Tiililä 2012). Puhuja (NE1) myös yksilöllistää potilaan 
personoimalla hänet yksikön toisella persoonalla sinun äiti -ilmauksessa sen sijaan, että viittaisi potilaaseen vain hän-pronominilla. Potilaan yksilöllistäminen tuo puheeseen myös empatian sävyä, mikä onkin yksi tapa synnyttää luottamusta asiantuntijan ja potilaan tai omaisen välisessä suhteessa (ks. Candlin \& Roger 2013: 52). Puhetilanteen henkilökohtaisuuden ja luottamuksen ilmapiiriä lisää myös kuulijan suora ja tuttavallinen puhutteleminen ja yhteisen tiedon korostaminen: sä tiedät.

Puhujan käyttämät kielelliset funktiot voivat tulla ymmärretyksi, vaikka hänen kielitaitonsa olisikin muodollisesti ja rakenteellisesti puutteellinen. Vaikka osallistuja NE4:n seuraavassa esimerkissä käyttämä kieli on rakenteellisesti horjuvaa, rauhoittelun funktio välittyy kuulijalle vaivattomasti. Kyse on samasta tehtävästä kuin edellä esimerkissä (3) eli valmistautumisohjeen antamisesta ennen tutkimusta; esimerkkiin on poimittu vain ote suorituksesta. Potilaan rauhoittelun tarkoituksessa NE4 nostaa esiin toimenpiteen hyviä puolia: tutkimus on kivuton ja turvallinen. Koska tuleva toimenpide koskee konkreettisesti juuri asianomaista henkilöä, hoitaja puhuttelee häntä suoraan yksikön toisessa persoonassa (sinä ei tarvi, sinun täytyy) ja kehottaa häntä olemaan jännittämättä ja pysymään rauhallisena.

(7) --- sinun ei tarvi, sinä ei tarvi, olen jännittää koska tämä koe on tosi varma ei ole kipua ei ole huonosti sinun elämää esimerkiksi röntgenissä, ja, sinun täytyy olen rauhallinen --- (NE4)

Osallistujista NE4 oli ainoa, jonka taitotaso oli yleisissä kielitutkinnoissa jäänyt pääosin alle tason 3; vasta puheen ymmärtämisessä hän oli saavuttanut tason 3. Huomattaviakin haasteita ilmenee siten sekä sujuvuuden, tarkkuuden että kompleksisuuden alueella, mutta tietyt ammatillisen kielenkäytön ulottuvuudet ovat tästä huolimatta jo hyvin hallinnassa. Huomionarvoista on, että tehtävä sisälsi vaativan tekstin ymmärtämistä ja sen mukauttamista luontevaksi puheeksi; ammatillisen tekstin ymmärtäminen ja rekisterinvaihdos onnistuivat yleiskielitaidon tasoon verrattuna huomattavan hyvin. Seuraavaksi tarkastellaan lähemmin juuri eri rekistereiden hallintaa osana työelämän kielenkäyttöä. 


\subsection{Ammatillinen ja yleinen rekisteri}

Lähes kaikkiin ammatillisen kielitaidon arviointikokeilun tehtäviin kuului rekisterinvaihdos: joko ammatillista erikoiskielistä lähdemateriaalia oli muunnettava sopivaksi kuulijalle, jolle alan terminologia on vierasta, tai arkikielisempää puhuttua materiaalia oli käsiteltävä kirjallisesti ammatillisen kielen rekisteriä käyttäen. Terveydenhuollon tehtävissä rekisterinvaihdosten hallinta on yksi keskeisimmistä kielellisistä käytänteistä (Bennink 2015: 65-67). Seuraavaksi tarkastellaankin lähemmin sitä, miten siirtymä ammatillisesta yleiseen rekisteriin onnistui kolmella eri osallistujalla. Kaikki esimerkit ovat samasta puhelinkeskustelua simuloivasta tehtävästä, jossa osallistujan tulee kertoa omaisille potilaan tilasta seuraavan hoitokertomuksen pohjalta (ks. myös esimerkit 5 ja 6 edellä):

Tullessa yleistila kohtalainen. Kalpea nainen. Vastailee asiallisesti. Sydämestä ja keuhkoista auskultoiden ei poikkeavaa. Vatsa palpoiden pehmeä, aristamaton. Jaloissa ei turvotuksia. Oikeassa lonkassa lateraalisesti kookas hematooma, suurin läpimitta reilusti $10 \mathrm{~cm}$, keskeltä pinkeä, kovahko. Lonkkaa kärsii hyvin liikutella. EKG:ssa flimmeri, RBBB. RR 107/52, saturoituu 3 ltr lisähapella 98 \%, Hb 51, leuk. 9.5, tromb 119, INR 6.6. Saanut Konakion 10 mg p.o.

Potilas otettu osastolle 7. Marevan tauotettu. Potilaalle tiputeltu 3 PSP, jolla hemoglobiini noussut ad 86. Osastolla lonkan hematooma hyvin jo sulanut, lonkkaa kärsii normaalisti liikutella. RR 122/71, p. 86, ei kuumeile, saturoituu 2 ltr lisähapella $97 \%$.

Potilas siirtyy seurantaan tk:n vuodeosastolle. TK:ssa vitaalien ja PVK:n seuranta. Mikäli saturoituu hi:lla yli $92 \%$, niin ei tarvitse happilisää. Hu pvk. Marevan edelleen tauotettuna, antikoagulaatioksi aloitettu Klexane $20 \mathrm{mg} \times 1$. s.c. Tk:ssa osastonlääkärin arvio, miten ak-hoito jatkossa toteutetaan.

Hoitokertomus sisältää tyypillisesti paljon yksityiskohtaista, ammatillisesta näkökulmasta esitettyä tietoa tiivistetyssä tekstimuodossa. Hoitokertomuksen sisällön referoinnissa korostuu puhujan taito käyttää arkikielisempiä parafraaseja, mikä taas onnistuakseen edellyttää 
myös hyvää tekstinymmärtämisen taitoa ja ammattisanaston hallintaa. Ammatillinen asiasisältö on ensin ymmärrettävä - vasta sen jälkeen sen voi muuntaa yleispuhekieliseen ilmaustapaan. Esimerkissä (8) osallistuja NE1 selittää potilaan tilannetta omaiselle ja ottaa taitavasti huomioon tämän rajalliset mahdollisuudet ymmärtää terveydenhuollon ammatillista käsitteistöä.

(8) katso, tämä viimeinen, kirjoitus ei nyt tarvitse lisähappe siis hän saturoituu elikkä hän hengittää hyvin ilman, lisähappee, tämä verenvuotojuttu elikkä hän ollu aikaisemmin Marevan-hoito, mutta, aika sitten oli, hänen arvo niin korkea, sitten, ollu verenvuotoriski, sen takia Marevan-lääke on tauotettuna nut, mutta, varten hoidetaan että nyt on, vuoteessa hoidossa, me pistetään Klexane Klexane se on semmonen lääke että, se hoitaa että ei oo, ei oo. (veren verin), varten parantaa hänen veren- verenkierto (NE1)

Hoitaja mainitsee tässä kyllä hoitokertomuksessa käytetyn ammattitermin saturoituu, mutta myös selittää sen arkikielellä ymmärrettävästi: elikkä hän hengittää hyvin ilman lisähappee. Haakanan ja Raevaaran (1999) mukaan tällainen ammatillisen ja arkikielisen sanaston rinnakkainen käyttö tai vuorottelu on potilaan kanssa käytävälle vuorovaikutukselle ominaista (ks. myös Linell 1988). Hoitaja myös avaa dokumentista ilmenevän lääkkeen vaihdon syitä. Yksi antikoagulantti on verenvuotoriskin vuoksi ensin jätetty pois ja sitten vaihdettu toiseen, mutta hoitaja ei käytä lähdetekstin termiä antikoagulaatio, vaan kuvaa lääkkeen vaikutusta lausemuotoisella parafraasilla se on semmonen lääke, että se parantaa verenkiertoa.

Tukeutuminen arkikielen käsitteisiin on tärkeää, mutta ei välttämättä helppoa; ammattilaisten kesken suositaan eksaktia alakohtaista terminologiaa, joka tyypillisesti on latinapohjaista ja sellaisena usein melko hyvin kielestä toiseen siirtyvää (Heimala-Kääriäinen 2015). Suomenkielinen asiakkaille tutumpi sanasto on hoitajan opittava erikseen.

Osallistuja NE3 turvautuu samassa tehtävässä lääketieteen termeihin hematooma ja antikoagulaatio, mikä voi johtua siitä, että niiden yleiskieliset ja samalla arkisemmat vastineet mustelma ja hyytymisenestohoito 
eivät ole vielä hallinnassa. Kyse voi olla myös laajemmista yleiskielitaidon puutteista, jotka estävät puhujaa käyttämästä kiertoilmauksia tai kuvaamasta asioita parafraasien avulla.

(9) kaatui, ja hänellä, oli lonkka murtuma, ja. iso hematooma oli, meni leikkaukseen, ja, --- nut annetan hänele, piikki vatsassa koska, ei saa antaa Marevan hänele. se on antikoagulaatio, aine, --- tällä hetkellä ei tarvitse, happilisä, koska, saturaatio on ihan normaali ja, hengitä, normaalisti, ja, --- (NE3)

Termiä saturaatio osallistuja NE3 kyllä selittää, mutta ei onnistu siinä aivan tyhjentävästi. Hän rinnastaa saturaation ja hengittämisen (saturaatio on ihan normaali ja, hengitä, normaalisti) ja saattaa näin saada aikaan vaikutelman, että kyseessä on ikään kuin kaksi toisiinsa liittymätöntä ilmiötä. Lisäksi NE3:n reseptiivisissäkin taidoissa vaikuttaa tämän hoitokertomuksen referointitehtävän perusteella olevan vielä kehitettävää ammatillisissa konteksteissa. Hän nimittäin esittää, että potilaalla oli lonkkamurtuma ja hän joutui leikkaukseen. NE3:Ita on siis jäänyt ymmärtämättä yksi dokumentin oleellinen tieto eli se, että potilaan kaatumisesta ei aiheutunut lonkkamurtumaa. On toki huomioitava, että keskitasolle sijoittuvilla kielenkäyttäjillä on ylipäänsä vielä kehittymässä oleva kielitaito.

Samassa tehtävässä osallistuja NE2 tuntuu puolestaan kohdanneen reseptiivisen kielitaitonsa rajat. Hän esittelee aluksi hoitokertomuksen sisältöä kuulijalähtöisesti, mutta siirtyy sitten lainaamaan dokumenttia suoraan, vaikkakin hieman epätarkasti ääneen lukien; tämä kohta on esimerkissä lihavoitu. Lainaaminen tapahtuu ilmeisesti siksi, että hän ei ymmärrä lukemaansa ainakaan siinä määrin, että voisi avata tekstiä asiaa tuntemattomalle kuulijalle. Ymmärtämisongelmat vaikuttavat myös siihen, että hoitaja ei pysty arvioimaan, kuinka relevanttia tieto kuulijan kannalta on.

(10) katsotaan jos tuntuu vähän parempi ja voi auttaa vähän kipuja menee pois, vielä, hänellä ollut kohtalaisesti, joo, ja hänellä ollut vähän kalpeaa, nainen ja sydämestä ja keuhkista, auskultoiden ei poikkeavaa, 
vatsa jos palpoiden on ollut pelmeä aristamaton, ja jaloissa ei ollut turbo, oikeassa lonkassa lateri vähän pieni ematooma --- verenpaine ollut sata, ja, alapaine ollut viisikymmentä saturointi on ollut kolme litrea lisähappe kate- yhdeksänkymmentäkahdeksa ja, ollut paha, emoglobiini ollut viisikymmentäyksi leukosiitto yhdeksänkymmentä piste viisi --- (NE2)

Otteen lopussa NE2 avaa ammatillisessa pohjatekstissä lyhentein ilmaistuja tietoja sanalliseen muotoon, kun lähdeteksti muuttuu luetteloksi verenpaine- ja laboratorioarvoja. Ne ovat sanastoltaan tuttuja ja yksiselitteisesti ilmaistuja numeraalisia tietoja, ja arvojen luetteleminen käy NE2:lta sujuvasti yksinkertaista eksistentiaalirakennetta $x$ (on) ollut $y$ käyttäen. Näitäkin tietoja NE2 kommentoi vain lyhyesti eikä kovin kohdekielisesti: ollut paha ei ilmauksena välttämättä heti aukea kuulijalle ilman tarkempaa selitystä. Ymmärrettävyys kuitenkin pääosin säilyy niissä kohdissa, joissa rekisterinvaihdos ylipäänsä toteutuu. Ääneen ja vieläpä epätarkasti artikuloiden luettu hoitokertomuksen ote sen sijaan jäisi kuulijalta tositilanteessa todennäköisesti ymmärtämättä.

\section{Lopuksi}

Analyysin tulokset osoittavat, että jo Yleisten kielitutkintojen tasolla 3 kielitaidon eri osa-alueilla olevat pystyvät ilmaisemaan vaativiakin kielellisiä funktioita oman alansa ammatillisessa kontekstissa, vaikka tuotos olisikin pintatasoltaan puutteellista. Eniten vaikeuksia funktioiden tuottamisessa ja lähdemateriaalien ymmärtämisessä ilmeni kaikissa tehtävissä vain osallistujalla, jonka taitotaso oli useimmissa YKI:n osakokeissa ollut alle tason 3, mutta hänkin sai itsensä ymmärretyksi ja onnistui seuraamaan monia ammatillisen kielenkäytön konventioita. Muut osallistujat pystyivät osoittamaan vahvaa ammatillista kielitaitoa ainakin useimpien tarkasteltujen funktioiden kohdalla: sekä ohjaaminen, tiedon välittäminen että turvallisuuden luominen onnistuivat hyvin, kuten myös siirtyminen rekisteristä toiseen. Jo tässä suppeahkossa artikkelissa analysoidut esimerkit tarjoavat evidenssiä kielellisten keinojen käytön 
luontevuudesta, joustavuudesta ja monipuolisuudesta eri tilanteissa. On myös huomionarvoista, että useimmat integroitujen tehtävien materiaalit olivat kielellisesti kompleksisia, abstrakteja ammattitekstejä, jotka vaativuudessaan ylittivät yleisten kielitutkintojen keskitason puheen- ja tekstinymmärtämisen tehtävien vaatimustason selvästi. Aihepiirin ja terminologian tuttuus kuitenkin mahdollistivat niiden käsittelyn.

Tekstitaitoajatteluun nojaavia ja rekisterinvaihdoksia edellyttäviä integroituja tehtäviä ei ole vielä yleisesti käytössä kielitaidon arvioinnissa. Integroidut tehtävät sinänsä ovat tavallisia monissa ESL-testeissä (Esmaeili 2002), ja niistä laajin on TOEFL iBT -testi, joka haastaa perinteisen tavan arvioida jokaista yksittäistä kielitaidon osa-aluetta erikseen (McNamara 2009; Bachman 2002). Niiden käyttöä voidaan pitää ammatillisessa kontekstissa erityisen perusteltuna: työelämässä laaditaan toistuvasti tekstejä puheen pohjalta ja kerrotaan asioista suullisesti tekstien pohjalta, mikä usein edellyttää myös rekisterinvaihtoa ja siihen liittyen terminologian mukauttamista tilanteen ja keskustelukumppanin mukaan. Rekisterinvaihto on haastavaa, mutta yleisten kielitutkintojen tasolla 3 olevat selviytyivät siitä ammatillisessa kontekstissa jo lupaavasti. Muutamat osallistujat pystyivät tekemään ammattiterminologiaa ymmärrettäväksi käyttäen sitä arkisen sanaston kanssa rinnakkain.

Palautekeskusteluissa kaikki neljä osallistujaa toivat esiin, että ammatillisen kielitaidon arviointikokeilun tehtävät olivat hyvin lähellä heidän normaalia työarkeaan ja tuntuivat siksi helpommiltakin kuin hieman aiemmin suoritettu yleisten kielitutkintojen keskitason testi, jossa aihepiirit ovat yleisiä eivätkä omaan ammatilliseen arkeen kiinnittyviä. Integroitujen tehtävien tuttuus ja autenttisuus perustuivat siihen, että todellisessa työelämässäkin vaaditaan tilanteesta riippuen holistista tai selektiivistä ymmärtämistä ja oma kielellinen tuottaminen on pitkälti muiden tuottamiin suullisiin tai kirjallisiin teksteihin nojaavaa. Ammatillisen kielitaidon arviointia voidaankin pitää nimenomaan työelämässä jo pidempään olleiden kohdalla reiluna käytänteenä, jos he voivat sen myötä osoittaa osaamisensa laajemmin kuin mitä vain yleiskielitaitoon keskittyvä kielitutkinto mahdollistaa ja tehdä näkyväksi 
juuri keskeisimpiä vahvuuksiaan - ehkä myös kompensoiden joitakin yleiskielitaitonsa puutteita (Hamp-Lyons 1991). Yleiskielitaidon puutteet näkyivät tässä aineistossa lähinnä perussanaston ja -rakenteiden tarkkuuden horjuntana sekä vaikeuksina ilmaista asiantuntijasisältöjä arkikielisin parafraasein. Nämä puutteet jäivät kuitenkin ammatillisen kielitaidon vahvuuksien ansiosta taka-alalle, kun päähuomio kohdennettiin työssä keskeisten kielellisten funktioiden ilmaisemiseen.

Tulokset ovat merkittäviä paitsi työelämässä tarvittavan kielitaidon arvioinnin myös kielikoulutuksen kannalta. Työelämään tulevilta odotetaan usein jokseenkin "valmista" kielitaitoa, mutta sellaista esimerkiksi Espanjasta rekrytoiduilla hoitajilla ei vielä tullessaan voinut suomen kielessä olla, vaikka he olivatkin osallistuneet intensiiviseen lähtömaakoulutukseen neljän kuukauden ajan. Palautekeskusteluista kävi ilmi, että heidän ensimmäinen työvuotensa Suomessa oli ollut kielellisesti hyvin vaativa, mutta samalla myös palkitseva: ennestään tuttuja työtehtäviä oli alkuun pitänyt tehdä uudessa ympäristössä kovin rajallisen kielitaidon varassa, mutta kielitaito oli toisaalta kehittynyt nopeasti nimenomaan työelämässä - siis työtä suomenkielisten parissa ja kanssa tehden.

Lähtömaakoulutukselle asetetaan helposti kovia odotuksia, mutta muutamassa kuukaudessa ei työssä tarvittavaa kielitaitoa voi ottaa haltuun, vaikka hyvän perustan sen hankkimiselle ehtisikin luoda (ks. Rainio 2013). Pääosa oppimisesta tapahtuu siis vasta työyhteisön tuella, työelämään osallistuen. Helsingin yliopistossa käynnistyi vastikään tutkimushanke, jossa pyritään kehittämään sairaalatyöyhteisöä palvelevia tapoja tukea kielenoppimista nimenomaan työtilanteissa. Oppimista voitaisiin varmastikin tehostaa myös tuomalla räätälöityä kielikoulutusta työelämän keskelle (ks. Mähönen 2014; Heimala-Kääriäinen 2015), ja tästä on Suomessa jo saatu käytännön kokemustakin.

Erityisesti niille, jotka vasta odottavat pääsyä oman alansa töihin Suomessa, tulisi myös luoda luontevia oppimismahdollisuuksia työelämään tiiviissä yhteydessä olevan kielikoulutuksen avulla, että heidän ammattitaitonsa ei menisi hukkaan uudessa asuinmaassa. Tähän tähtäävä valtakunnallisen koulutusmallin kehittämishanke onkin jo käynnissä. 


\section{Lähteet}

ABIM 2015. American Board of Internal Medicine. www.abim.org (27.2.2016).

Bachman, Lyle F. 2002. Some reflections on task-based language performance assessment. - Language Testing 19 (4), 453-476. http://dx.doi. org/10.1191/02655322021t240oa

Bennink, Ashley 2015. Searching for understanding in the medical consultation. Accomodation and the use of dialect variants among Latino patients. Magdalena Zabielska, Emilia Wąsikiewicz-Firlej, Anna Szczepaniak-Kozak (Eds.), Discourses in co(n)text: The many faces of specialised discourse. Newcastle upon Tyne: Cambridge Scholars Publishing.

Brown, Penelope, Stephen C. Levinson 1987 [1978]. Language and Politeness. Some Universals in Language Usage. Studies in Interactional Sociolinguistics 4. Cambridge: Cambridge University Press.

Candlin, Christopher N., Sally Candlin 2002. Discourse, expertise and the management of risk in the health care settings. - Research on Language and Interaction 35 (2), 115-137. http://dx.doi.org/10.1207/S15327973RLSI3502_1

Candlin, Sally, Peter Roger 2013. Communication and Professional Relationships in Healthcare Practice. Sheffield: Equinox.

De La Croix, Anne, John Skelton 2009. The reality of role-play: Interruptions and amount of talk in simulated consultations. - Medical Education 43 (7), 695-703. http://dx.doi.org/10.1111/j.1365-2923.2009.03392.x

Duff, Patricia, Ping Wong, Margaret M. Early 2002. Learning language for work and life: The linguistic socialization of immigrant Canadians seeking careers in health care. - Modern Language Journal 86 (3), 397-422.

Elder, Cathie, John Pill, Robyn Woodward-Kron, Tim McNamara, Elizabeth Manias, Gillian Webb, Geoff McColl 2012. Health professionals' views of communication: Implications for assessing performance on a healthspecific English language test. - TESOL Quarterly 46 (2), 409-419. http:// dx.doi.org/10.1002/tesq.26

Esmaeili, Hameed 2002. Integrated reading and writing tasks and ESL students' reading and wrriting performance in an English language test. - Canadian Modern Language Review 58 (4), 599-622. http://dx.doi.org/10.3138/ cmlr.58.4.599

Hamp-Lyons, Liz 1991. Pre-text: Task-related influences on the writer. - Liz HampLyons (Ed.), Assessing Second Language Writing in Academic Contexts. Norwood, NJ: Ablex, 127-151. 
Haakana, Markku, Liisa Raevaara 1999. Divertikkeleitä vai pussukoita? - Lääketieteen kieli vuorovaikutuksessa. - Kielikello 3/1999.

Heimala-Kääriäinen, Elina 2015. Seurassa parempaa sairaalasuomea: ammatillisen kielitaidon oppiminen ja kollegojen kielellinen tuki sairaalaympäristössä. Maisterintutkielma, Jyväskylän yliopiston kielten laitos. http://urn. fi/URN:NBN:fi:jyu-201506192388

Honkanen, Suvi 2012. Kielioppi ja tekstilaji. Direktiivin muotoilusta viraston ryhmäkirjeissä. Helsinki: Helsingin yliopisto.

Hyvärinen, Riitta 2005. Millainen on toimiva potilasohje? Hyvä kieliasu varmistaa sanoman perillemenon. - Duodecim 121 (16), 1769-1773.

Härmälä, Marita 2008. Riittääkö Ett ögonblick näytöksi merkonomilta edellytetystä kielitaidosta? Kielitaidon arviointi aikuisten näyttötutkinnoissa ['Ett ögonblick a sufficient demonstration of the language skills required in the Qualification of Business and Administration? Language assessment in compe- tence-based qualifications for adults']. Jyväskylä Studies in Humanities 101. Jyväskylän yliopisto. http://urn.fi/URN:ISBN:978-951-39-3340-1

Kela, Maria, Johanna Komppa 2011. Sairaanhoitajan työkieli: yleiskieltä vai ammattikieltä? Funktionaalinen näkökulma ammattikielen oppimiseen toisena kielenä ['Nurse's language needs - Standard language or professional language? Functional approach to professional second language learning']. - Puhe ja kieli 31 (4), 173-192. http://ojs.tsv.fi/index.php/pk/ article/view/4752

Komppa, Johanna, Tuula Jäppinen, Marja Herva, Taija Hämäläinen 2014. Korkeakoulutuksen ammatilliset suomi toisena kielenä -viitekehykset. Metropolia Ammattikorkeakoulun julkaisusarja Aatos-artikkelit 16. Helsinki: Metropolia Ammattikorkeakoulu. http://www.metropolia.fi/fileadmin/ user_upload/Julkaisutoiminta/Julkaisusarjat/AATOS/PDF/METROPOLIA_AATOS_16.pdf (30.9.2016).

Linell, Per 1998. Discourse across boundaries: On recontextualizations and the blending of voices in professional discourse. - Text 18 (2), 143-157. http:// dx.doi.org/10.1515/text.1.1998.18.2.143

Martin, Maisa, Sanna Mustonen, Nina Reiman, Marja Seilonen 2010. On becoming an independent user. - Inge Bartning, Maisa Martin, Ineke Vedder (Eds.), Communicative Proficiency and Linguistic Development: Intersections Between SLA and Language Testing Research. EUROSLA. Monographs series 1. European Second Language Assosiation. Rome: Edisegno srl, 57-80. http://eurosla.org/monographs/EM01/57-80Martin_et_al.pdf (30.9.2016). 
McNamara, Tim 2009. Principles of testing and assessment. - K. Knapp, B. Seidlhofer, H. G. Widdowson (Eds.), Handbook of Foreign Language Communication and Learning. New York: Mouton de Gruyter, 607-628.

Moore, Tim, Janne Morton, David Hall, Chris Wallis 2015. Literacy practices in the professional workplace: Implications for the IELTS reading and writing tests. IELTS Research Reports Online Series 1. London: Bristish Council. https://www.ielts.org/teaching-and-research/research-reports/onlineseries-2015-1 (30.9.2016).

Mähönen, Elina 2014. Maahanmuuttajalääkärin kokemuksia ammatillisen kielitaidon kehittymisestä: "No se mun kurssi oli töissä”. Maisterintutkielma, Jyväskylän yliopiston kielten laitos. http://urn.fi/URN:NBN: fi:jyu-201501201153

Northouse, Laurel L., Peter G. Northouse 1998. Health Communication. Strategies for Health Professionals. Third edition. Stamford (Conn.): Appleton \& Lange.

OKM 2014 = Kielitaidon määrittäminen sekä kielitaidon ja EU/ETA-alueen ulkopuolella hankitun koulutuksen täydentäminen terveysalalla. Opetus- ja kulttuuriministeriön työryhmämuistioita ja selvityksiä 2014:5. Helsinki: Opetus- ja kulttuuriministeriö. http://www.minedu.fi/OPM/Julkaisut/2014/kielitaito_terveysalalla.html (30.9.2016).

Paananen, Jenny 2015. Kuinka eleet helpottavat yhteisymmärrystä? Ikoniset ja deiktiset eleet monikulttuurisilla lääkärin vastaanotoilla ['How does gesturing facilitate mutual understanding? Iconic and deictic gestures in multicultural general practice consultations']. - Puhe ja kieli 35 (2), 73-95. http://ojs.tsv.fi/index.php/pk/article/view/51354 (30.9.2016).

Piikki, Anni 2010. Terveydenhoitoalalla riittävä suomen taito - mitä se on? Sutina 1, 30-33.

Pill, John 2013. What doctors value in consultations and the implications for specific-purpose language testing. Unpublished PhD Thesis. The University of Melbourne.

Pill, John 2016. Drawing on indigenous criteria for more authentic assessment in a specific-purpose language test: Health professionals interacting with patients. - Language Testing 33 (2), 175-193. http://dx.doi. org/10.1177/0265532215607400

Raunio, Pirjo 2013. Työhön Suomeen? Tutkimus työperusteiseen maahanmuuttoon liittyvistä koulutusprosesseista ['Moving to Finland for Work? Dissertation of the processes concerning pre-departure training and labor 
migration']. Acta Electronica Universitatis Tamperensis 1331. Tampere: Tampereen yliopisto. http://urn.fi/URN:ISBN:978-951-44-9209-9

Roberts, Celia, Shrikat Sarangi 2005. Theme-oriented discourse analysis of medical encounters. - Medical Education 39 (6), 632-640. http://dx.doi. org/10.1111/j.1365-2929.2005.02171.x

Sarangi, Shrikat 2010. Healthcare interaction as an expert communicative system: An activity analysis perspective. - Jürgen Streeck (Ed.), New Adventures in Language and Interaction. Amsterdam: John Benjamins, 167-197.

Seilonen, Marja 2014. “Tuntuuko, jos tästä painaa?” Epäsuoruus, toimintaan kehottaminen ja ammatillisuus [“Does it hurt, if one presses here?" Indirectness, urging action and professionality in the texts of health care professionals']. - Lähivõrdlusi. Lähivertailuja 24, 221-243. http://dx.doi. org/10.5128/LV24.08

Seilonen, Marja, Minna Suni 2015. Puhetta työstä: kansainvälisten terveydenhuollon ammattilaisten suomen kielen puhumistaidon arviointi. - Ammattikasvatuksen aikakauskirja (17) 2, 27-43.

Tervola, Maija, Anneli Pajunen, Seppo Vainio, Mari Honko, Kari Mattila 2015. Maahanmuuttajataustaisten lääkärien suomen kielen taito laillistamiskuulustelussa ['Finnish language proficiency of immigrant physicians in medical licensure examinations']. - Duodecim 131 (4), 339-346. http://urn.fi/ URN:NBN:fi:uta-201602251249

Tiililä Ulla 2010. Sanoilla lavastettu virasto. Tietoyhteiskunnan arkea sosiaalija hoiva-aloilla. - Marjut Johansson, Pirkko Nuolijärvi, Riitta Pyykkö (Toim.), Kieli työssä. Asiantuntijatyön kielelliset käytännöt. SKST 1311. Helsinki: Suomalaisen Kirjallisuuden Seura, 162-189

Tiililä, Ulla 2012. Tekstilajit kielenhuollossa. - Kielikello 4. Tilastoraportti 2012. Helsinki: Tilastokeskus.

Virtanen, Aija 2010. Onko filippiiniläisillä hoitajilla suomen kieli hallussa? Käsityksiä ammatillisesta kielitaidosta ja sen riittävyydestä hoivatyössä. Pro gradu -tutkielma, Jyväskylän yliopiston kielten laitos. http://urn.fi/ URN:NBN:fi:jyu-201006152064

Virtanen, Aija 2011. Käsityksiä kansainvälisesti rekrytoitujen hoitajien ammatillisesta kielitaidosta ja sen kehittymisestä. Mediakeskusteluiden ja asiantuntijan haastattelun analyysia ['Beliefs about international nurses' work-related language skills and their development. Analysis of media discussion and an expert interview']. - Puhe ja kieli 31 (4), 153-172. http:// ojs.tsv.fi/index.php/pk/article/view/4751/4469 (30.9.2016). 
Virtanen, Aija 2013. Minä sairaanhoitajana: tulevaisuuden minuudet motivaatiota muokkaamassa ['I as a nurse: future selves making the motivation']. - Lähivõrdlusi. Lähivertailuja 23, 403-427. http://dx.doi.org/10.5128/LV23.16

Virtanen, Aija (ahead of print) 2015. The multivoicedness of workplace literacies: An international nursing student documenting in a second language. European Journal of Applied Linguistics. http://dx.doi.org/10.1515/eujal2015-0015

VISK = Auli Hakulinen, Maria Vilkuna, Riitta Korhonen, Vesa Koivisto, Tarja Riitta Heinonen, Irja Alho 2004. Ison suomen kieliopin verkkoversio ['Grammar of Finnish']. Helsinki: Suomalaisen Kirjallisuuden Seura. http://scripta.kotus.fi/visk (21.5.2016).

Zetkulic, MaryGrace 2011. By the bedside: Lessons about Communication from an Internal Medicine Program director. - Barbara J. Hoekje, Sara M. Tipton (Eds.), Innovation and Leadership in English Language Teaching. Volume 5: English Language and the Medical Profession: Instructing and Assessing the Communication Skills of International Physicians. Leiden, NLD: Emerald Insight, 133-146. 


\title{
Advice, information and safety by means of language: internationally recruited nurses demonstrating their professional Finnish language skills
}

\author{
MARJA SEILONEN, MINNA SUNI \\ University of Jyväskylä
}

The focus of this paper is on the professional language used by four internationally educated nurses working in Finnish in Finland. The data comes from a tailor-made professional language test module including integrated material-based tasks. The module was designed by the project Health care Finnish: developing and assessing Finnish proficiency among health care professionals (2014-2015) to complement the skill profiles based on the test results of the National Certificates of Language Proficiency (NCLP) intermediate level test.

None of the participants had yet reached the level B2 in Finnish, and one of them had reached level B1 in speaking comprehension only. Level B1 (level 3 in NCLP) is currently the level required for authorization in the Finnish health sector for non-EU/EEA health care professionals. However, there are official suggestions that, in the future, the requirements be raised to level B2 (level 4 in NCLP) and also cover EU/EEA educated professionals (Ministry of Education 2014). Assessment of professional language skills has also been suggested, but no decisions have been made on this yet.

The aim of the qualitative analysis of the test performance data was to find out how the participants utilize different syntactic, lexical and pragmatic resources to express communicative functions such as giving instructions and documenting information, which are typical for health communication. Also under scrutiny was their ability to shift between professional and colloquial language use.

The results of this analysis and the content analysis of the feedback interviews used as background data suggest that the four participants with one year of work experience in Finland are even more confident with the professional language than with the "general language". This clearly shows that their language proficiency has mainly developed in the work environment. In spite of some 
obvious problems with grammatical and lexical accuracy, the participants were able to perform work-related linguistic functions such as giving advice, providing information and calming down the patient in a fluent and comprehensible manner and to shift between professional and colloquial registers rather smoothly.

Such internationally educated professionals who already are employed in Finland would certainly benefit from language education organized in close connection to their daily working life and the tasks performed there. Similarly, those still seeking employment would benefit from tailor-made language courses with work-related content.

Keywords: Finnish as a second language; migration; professional language; language assessment; health communication

\section{Marja Seilonen}

University of Jyväskylä, Department of Languages P.O. Box 35

40014 Jyväskylä, Finland

marja.a.p.seilonen@jyu.fi

\section{Minna Suni}

University of Jyväskylä, Department of Languages P.O. Box 35

40014 Jyväskylä, Finland

minna.suni@jyu.fi 